\title{
Exploring The Affective Dimension Of Teachers' Work In Alternative School Settings
}

Kitty te Riele*

Victoria Institute, Victoria University, Melbourne, Australia

kitty.teriele@vu.edu.au

Martin Mills

School of Education, University of Queensland, Brisbane, Australia

m.mills@uq.edu.au

Glenda McGregor

School of Education and Professional Studies, Griffith University, Brisbane, Australia

g.mcgregor@griffith.edu.au

Aspa Baroutsis

School of Education, University of Queensland, Brisbane, Australia

a.baroutsis@uq.edu.au

*Corresponding Author:

Victoria Institute

City Queen Campus

PO Box 14428

Melbourne VIC 8001

Australia

kitty.teriele@vu.edu.au 


\section{Exploring The Affective Dimension Of Teachers' Work In Alternative School Settings}

The affective dimension of teachers' work is a vital element in shaping inclusive, child-centred classrooms. It is particularly important for students who lack certain aspects of care and support within their personal lives. Recently, neoliberal educational paradigms of data gathering, external testing, and competition have increased pressure upon students and teachers in mainstream schools. Many teachers feel that they have been taken away from their core business of teaching and caring for young people. Students with the highest needs often leave or become excluded from mainstream settings; some find their way to alternative/flexi/second chance schools. Our research indicates that within such sites, teachers and workers appear to be committed to the implementation of an educational environment and ethos explicitly framed by concepts of affective justice and an ethics of care. Despite its challenges and because of its rewards, they strongly assert the significance of their emotional labour when working with, usually disadvantaged, young people and helping them to overcome marginalisation. We contend that this redefinition of schooling as inherently 'relational' implies forms of teacher activism that transcend the obligation to student 'well-being' as commonly understood in mainstream settings, and which is failing to meet the needs of many young people.

Keywords: care; emotion; social justice; teachers’ work; alternative schools

\section{Introduction}

The idea of 'The relational school' (Smyth, Down \& McInerney, 2010) or 'No education without relation' (Bingham \& Sidorkin, 2004) has become increasingly difficult to realise in schools that are under pressure from neoliberal regimes to prioritise obtaining strong results on national and international testing, enforcing student discipline, and safeguarding their image in the educational marketplace. As Kostogriz (2012, p. 401) argues such practices "target the relational foundation of teaching”. This does not mean that staff in mainstream schools do not care about students and do not value good relationships; however, they too often feel there is little scope for such 
affective work, expressing a sense of nostalgia for times past and regret about the changed nature of their job (Blackmore, 2004, p. 443). The effects of neoliberal educational policy settings on various aspects of schooling have been widely noted in research (see for example, Apple, 2004, 2006, 2010; Ball, 2012; Hardy, 2013). It is not our intention to replicate the body of such work; rather, this provides a context for this paper which examines the increasingly 'unseen' and 'hard to do' element of teachers' work - the relational - within alternative school settings.

One consequence of the competitive pressures of current mainstream schooling systems has been the exit of some teachers who have found employment in alternative schools where the ethos is quite different and they are able to engage in practices that originally drew them to teaching (see McGregor \& Mills, 2014). Whilst the research on which this paper draws began with a focus upon the experiences of the young people who attended alternative schooling sites and programs, we became increasingly interested in the ways in which such places and spaces facilitated a different relational environment that appeared to assist in the formation of staff/student relationships that were mutually respectful and more democratic than would have been possible within the contexts of conventional, hierarchical models of schooling that dominate the mainstream sector. Indeed, the 'relational environments' that we encountered in the alternative settings supported all other significant elements of the schools: high expectations, behaviour, attendance, pedagogy; the curriculum; and future pathways. Fundamentally, it appeared to come down to a sense of 'trust' and a sense that even if students faltered they would always have another chance, that it was acceptable to fail and try again. It is the centrality of the relational framework of these settings that engenders academic interest in the work of the teachers in them. 
Staff and students in our research across several projects in many different alternative school settings around Australia, as well as in research by others on alternative education nationally and internationally (e.g. Evans, Meyer, Pinney \& Robinson, 2009; Mills \& McGregor, 2014; Te Riele, 2012; Thomson, 2014; also see other papers in this special issue), affirm the central importance of the relational and affective dimensions of school, particularly for students who have experienced marginalisation both in schooling and in society. It is not uncommon for teachers to express how they, too, had felt like 'square pegs in round holes' in conventional schools (McGregor \& Mills, 2012). A positive relational culture in alternative schools is central to distinguishing them as communities which both workers and students want to attend. We argue that attention to the affective dimension of schooling contributes to enhanced curriculum and improved learning achievements, as well as to making traditional, often punitive, behaviour management redundant. Students in our research located in alternative schools frequently commented on the care and positive connections they experienced in these settings, for example:

They care, they care a lot about the students. No matter who you are they care ... Because they're so sweet, they do so much for the students here and more than what other schools would do because the way I've seen in other mainstream schools is you're a teacher, you teach, that's it. They're more caring. Like I say, it's like a community, it's like a family. So the teachers really care about the students and they're also youth workers as well so they deal with the children. If you have something on your mind you talk to a teacher and they're full open with you and they're so nice, they're just the most nicest people here. (Audrey [pseudonym], student, Boronia Flexi School)

In other publications, we have reported on students' insights regarding affective justice (Mills, McGregor, Baroutsis, Te Riele \& Hayes, 2015). In this paper, however, our focus is on the perceptions of the teachers, and sometimes youth workers and volunteers 
who also enact informal moments of teaching, who work with young people in alternative educational settings. In the next section we discuss the conceptual tools we draw on for analysis: affective justice, ethics of care and affective labour. Following an overview of our research project we present an analysis of staff interviews, in terms of how they perceive the affective dimension of their work in alternative settings as well as their views on sustaining this emotional labour.

\section{Affective justice, ethics of care and emotional labour}

In its genesis, our research was informed by Nancy Fraser's framework of social justice. Fraser (2009) argues that distribution, recognition and representation are interrelated components of social justice, and that all three are necessary to achieve parity of participation for all people in society. Distribution (the economic dimension of justice) requires a redistribution of resources based on need (Fraser, 1996). For young people in our research this may include access to subsidised public transport or funding for textbooks that enable them to participate in education. Recognition addresses the cultural dimension in Fraser’s framework and involves acceptance and valuing of differences (Fraser, 1996). In our research this means, for example, recognising students’ strengths rather than focusing on their perceived deficits. Finally, representation (the political dimension of justice) requires that people, including school students, are enabled to make representations on matters that impact on them (Fraser, 2009). This framework has proven fruitful in our own and others' writings in the context of education (Keddie, 2012; Mackie \& Tett, 2013; Mills, McGregor, Hayes \& Te Riele, 2015). However, in more recent work, we have added explorations of contributive justice and affective justice (Mills, McGregor, Baroutsis, et al., 2015). The latter is relevant to our analysis here. 
Our paper brings together Fraser's three conceptualisations as they relate to the affective dimension of teachers' work that are usually discussed separately. Therefore, combining existing scholarship and utilising notions of affective justice (Lynch, 2012); ethics of care (Noddings, 2003) and affective labour (Hochschild, 1983; Blackmore, 2004; and Kostogriz, 2012) enables us to build and extend previous research in the field.

\section{Affective Justice}

Affective justice, as advocated by Kathleen Lynch (2012) in her critique of Fraser’s theory, seeks to recognise the affective domain of life as a site of social practice distinct from the economic, cultural and political, albeit (as with all these three areas) with significant intersections. Addressing issues of affective justice requires a focus on two key issues: who receives 'care' and who does 'care work'. For Lynch there are three sets of relations integral to this work and to achieving 'affective equality': love, care and solidarity. Love entails intimate relations, high levels of interdependency and intense engagement, and applies mainly to close family, such as partners, children and parents. Care relations are those more likely to be found in school settings. While such relations do not have the intensity, or indeed obligations, of love relations, they are significant relations that involve close friends, colleagues, and - in the case of schools teacher student relations. Solidarity relations are not dependent on knowing the people involved; they are the political face of affective equality and relate to advocacy work for distinct populations of, for example, refugees or homeless youth.

For the schools in our research we can distinguish between care and solidarity relations by the way in which staff and students developed relationships, and the ways in which workers (and sometimes young people) were advocates for all marginalised young people. In terms of schooling then, the affective sphere is concerned with the 
quality of relationships, care and support available to students and with advocacy for young marginalised people as a social group. The receiving of care and solidarity within schools is important for achieving socially just outcomes for marginalised young people. However, in terms of the 'doing' of this work we are concerned here with the experiences, joys and costs to the teachers, youth workers and other adults working in alternative educational settings, of undertaking these forms of labour.

\section{Ethics of care}

A further set of conceptual tools to explore the affective dimension of educators' work is provided through Nel Noddings' exposition of 'ethics of care'. In contrast to the work of Fraser and Lynch, Noddings' scholarship is situated specifically within the domain of education. She conceives of teaching as a relational practice and argues teachers must "be committed to establishing and maintaining relations of care and trust” (Noddings, 2003, p. 250). Ethics of care is based on the dyad of the carer or 'one-caring' and the person 'cared-for'. In Noddings' view, caring is not complete without some form of recognition from the latter of the care by the former. However, most of the responsibility lies with the one-caring.

To achieve ethical caring, Noddings (1984) points to two major practices. First, 'engrossment' which refers to paying full attention to another person in order to gain a greater understanding of that person and as a consequence be better informed to provide care. Secondly, 'motivational displacement' where the behaviour of the one-caring is directed away from self-interest and towards the needs and interests of the person caredfor. Finally, it is useful to point out that Noddings recognises that: "Not every want rises to the level of a need" (2005, p. 149). To decide whether it does, she suggests the 'want' must meet these criteria: be stable over time and/or intense; clearly linked to a desirable 
end; and be feasible for the one-caring to meet. In addition, the person with the 'want' ought to be able and willing to contribute to satisfying their 'want'.

\section{Affective labour}

One critique of Noddings' ethics of care is the pressure to always be the 'one-caring' for others potentially contributes to exploitation of and burn-out among educators (Hoagland, 1991). Of use here is the notion of 'emotional labour': “The work involved in dealing with other people's feelings, a core component of which is the regulation of emotions” (James, 1989, p. 15). Hochschild (1983), widely credited with launching this concept, explains that emotional labour includes both expressing emotions that may not be felt (for example through a friendly smile to a difficult customer) as well as suppressing 'inappropriate' emotions (such as anger or frustration with the same customer). Hochschild (1983) particularly focuses on emotional labour as a commodity that generates commercial benefit for the employer but is to the detriment of employees. In contrast to the concepts of affective justice and ethic of care, emotional labour therefore has a negative character, both in terms of its impact on the staff member, and in terms of its lack of authenticity.

In education, the emotional nature of teachers’ work has been linked with increased stress and burnout (Hopman \& Drake, 2015). Blackmore (2004, p. 440) highlights the anger teachers and principals feel about the "dissonance between what they referred to as their 'real work' and the type of performative work required by systems and markets that was taking up their time and energy”. Teaching in contemporary schools is "passionate, emotional and political work” (Blackmore, 2004, p. 444), making the notion of emotional labour as proposed by Hochschild relevant. It also, however, signals another possibility - that educators deploy their passions and emotions towards grassroots political work against the imposition of neoliberal policies. 
This perspective is powerfully argued by Kostogriz (2012, p. 410) in his discussion of teachers’ affective labour states:

While these policies [of performance indicators and accountability] attempt to manage teachers' heads, affective labour enters the world of standards-based reform by the back door, prompting the question of what can be done with what one feels and cementing a sense of solidarity. There is an ethic behind the teachers' affective labour - the ethic of the heart that cannot be managed.

Kostogriz's thesis resonates with our work. His reference to solidarity evokes Lynch's similar notion of solidarity and advocacy for unknown people. His insistence on "the origin of teaching as a ‘caring' profession” (p. 402) connects Kostogriz’s arguments directly with the work by Noddings on an ethics of care. Kostogriz's approach is, however, more explicitly political than Noddings' - aligning with the conceptualisations of social justice by Lynch (2012) and Fraser (2009).

Defining affective labour as "the labour of interaction and social relations" (p. 399) and affect as involving “both reason and passions” (p. 407), Kostogriz (2012) shows how affect can empower teachers and how their affective labour can form "a foundation for democratic and ethical teaching practices” (p. 407). In our conceptual framework, therefore, we incorporate Hochschild's cautions relating to the cost of emotional labour as well as Kostogriz's recognition of the empowering notion of affective labour.

\section{Method}

The scope of our project was shaped by applying a social justice perspective to alternative schools. For our case studies we looked for those sites that provided learning opportunities for students who had experienced educational and social disadvantage. Not included were schools with alternative philosophies (such as Steiner) or behaviour 
management schools for students excluded from their schools.

Secondary schooling in Australia comprises Years 7-12. This paper is based on data from three urban secondary alternative schools in three different state /territories in Australia. They cater for students for whom 'the mainstream' (conventional forms of schooling) did not work well (see the next section). All names of sites, educational programs and people used in this paper are pseudonyms. The schools reported on in this paper are:

- Banksia College: conventional government school (Years 11-12) with two alternative programs for disadvantaged students: one for pregnant and parenting young people, ‘Banksia College Young Parents’ Program and the other a project-based curriculum, 'Banksia College Problem-Based Learning Program’, for young people looking for a more flexible and supportive learning environment.

- Boronia Flexi School: an alternative school (Years 7-12), which is part of a national network of schools under the auspices of a major church education organisation.

- Elkhorn Community College: an independent, non-government alternative school (Years 10-12).

All schools (or, for Banksia College, the two programs) are relatively small, with between 60-300 students enrolled at any one time.

After having sought relevant permissions, we adopted ethnographic approaches in our research (e.g. Mills \& Morton, 2013), including document collection, informal visits, meetings, ethnographic observations, and individual or small group interviews. This paper draws mainly on staff interview transcripts. For this project 24 staff and 45 
students took part in semi-structured interviews across these three sites. At one site, another nine staff interviews were conducted for a separate research project with the same researcher and by mutual agreement these were also analysed for this paper (see the Acknowledgements).

Initial analysis for earlier papers highlighted that issues to do with affect, emotion and care were frequently raised by participants. For example, workers often referred to their physical and emotional exhaustion whilst also noting points of intense satisfaction derived from working with the young people. They worried about the students when they did not come to school and instituted practices of care rather than punishment for absenteeism; for example, they would telephone young people with a view to asking whether they were 'okay' and 'was there anything they could do to help’. For this paper, these concepts formed the starting point for applying wellestablished procedures for thematic analysis (Merriam, 2009; Miles \& Huberman,1994) afresh to the staff transcripts. Our research explores the affective dimension of teachers' work in alternative schools. As such, drawing on data from teachers in different settings builds on existing scholarship using the above conceptualisations, but also brings a new dimension that does not focus on conventional schooling. The results of the analysis utilising the three conceptualisations of affective justice, ethics of care, and affective labour are presented below. Before that, however, it is useful to sketch the young people's life and previous schooling experiences that form the context for the work of staff at the sites.

\section{Setting the scene}

Whilst noting the diversity of student populations, those young people who typically find their way to alternative schools have usually experienced a range of personal, social and economic challenges. In terms of life experiences, this can include poverty, 
mental illness, teenage parenthood, out-of-home care, racism, homelessness, drug dependency, juvenile justice, refugee status, and trauma. Many of these experiences can be cast in social justice terms, for example they can be seen to have been caused by institutional racism and misogyny, and by economic oppression. In relation to their previous school, bullying, being failed, a lack of relevance of the curriculum, and conflict with staff were common experiences for the students we interviewed (and also in other research, see: Bridgeland, Dilulio \& Morison, 2006; Evans et al., 2009; Mills \& McGregor, 2014; Te Riele, 2012). Although for this paper we focus on staff data, in the spirit of representational justice (Fraser, 2009) comments on students' challenges below are drawn from the young people themselves.

Educational marginalisation was often intensified by difficult life circumstances, such as homelessness or pregnancy, as these students explain:

I was living in really unstable accommodation and picking up, like, five subjects while not even having Internet or a computer to do the assignments that came so often. [Lara, Banksia College Problem-Based Learning Program]

I was 7 months [pregnant] when I told my parents. ... my mum went in there [former school’s principal office] and she was like, "Can she finish Year 9?", [... but .... I was a bad influence on all the other girls, apparently. That's what he told mum, but in a bit harsher words. [Khloe, Banksia College, Young Parents' Program]

While acknowledging the significant impact of social injustices, for some students the key issue was educational disenfranchisement. As with Chelsea (Boronia Flexi School) this could be due to a lack of support for learning: "I found it very difficult at my old school to try and concentrate and learn. I was always behind with that and they didn't really help me out”. Also common was conflict with teachers, with students sometimes feeing 'picked on' for no reason or unsure why their relations with teachers were so 
negative. Lara (Banksia College) said: “My private schools, teachers, I don't know, it seemed liked they hated me and they didn't respect me at all”.

The ways in which these students contrasted those experiences with the ones in the alternative settings was often dramatic. This level of contrast may well have been because the purpose of education in these settings is often conceived holistically, integrating learning and credentials with personal development and connection with community. This was explained by staff member from Banksia College, Jack:

My view there was that, yes, it is nice if they end up with a certificate but there's a lot more to these programs than certification as a whole. What these programs are doing is, they are really drawing students who haven't had access to education back into education but not only back into education, back into mainstream society, back into developing a trust with adults that lots of them had lost. And those things were for me way more valuable than their Year 10/12 certificate.

Reminiscent of Noddings' (1984) concept of motivational displacement, the purpose of education in these alternative schools was largely determined by the (perceived) needs and interests of the students. This purpose formed the basis for specific affective practices by staff, as discussed below.

\section{Relations and care}

\section{Personal connections}

Staff we talked with, whether teachers or youth workers, highlighted the way they endeavoured to make personal connections with students. Fraser's (1996) idea of recognition as a component of social justice is evident in Edie's' comment:

They just love to feel like someone gets them. I think that is the biggest thing. ... once I get it and I let them know and relate it to something in my life, then you just see all the tension just go. [Edie - Big Picture Banksia College] 
Recognising students on their terms - teachers 'getting them' - relies on 'engrossment' (Noddings, 1984). For example, Edie actively worked to develop a greater understanding of her students. In Noddings' framework, such engrossment is necessary for caring because an individual's personal and physical situation must be understood before the one-caring can determine the appropriateness of any action. As Garth explained:

A lot of the students come in here and feel nervous about starting, about their skills and what they don't know. When you look at what works, it's because there's a relationship within the teacher and the student. [Garth - Banksia College]

Importantly, staff were connecting with students as fellow human beings, rather than in a patronising manner by staff as the 'one-caring' (Noddings, 1984). This invokes a sense of affective justice, in Lynch’s (2012) terms, with staff actively listening to young people - not deciding on their behalf what they thought students needed. As Kostogriz (2012, p. 409) argues:

...people enter the intersubjective space of the zone [of human contact] as subjects, rather than being perceived as objects that should be instructed and measured. Hence, effective teachers are necessarily affective; their affective labour in the zone of collaboration, dialogical inquiry and relational ethics de-reifies the students, increasing their power to learn.

Fleur (Elkhorn Community College), a former youth worker as well as a teacher, agreed that such personal connections between staff and students opens doors: "We have the possibility because we get to connect with them and we talk to them as human-beings”.

\section{Care for learning and for wellbeing}

Caring relationships are not only an end in themselves they also support learning. Catherine (Boronia Flexi School) explained: 
If everything's hitting the fan at home, you're not going to be able to concentrate and learn in class. And the whole idea of being inclusive, time-in rather than timeout, all these approaches to having positive relationships with young people and using that relationship and your knowledge of them to engage them in learning.

Such an approach has support in the literature, as Kostogriz (2012, p. 402) argues: "teaching is the affective labour of opening up a social learning environment and creating a mood for learning”. He suggests that teachers' affective labour generates "feelings of trust and care, well-being and respect, passion and excitement, satisfaction and happiness" which in turn "lead to, and correlate with, the production of intellectual effects such as knowledge, meanings, and understandings” (2012, p. 402).

Care that supports learning also means using curriculum and pedagogy in ways that engage young people in learning without repeating or reinforcing students’ prior experiences of failure (Hayes, 2012). Charlotte (Boronia Flexi School) was adamant that: "If you've got a teacher that's got a good relationship with the student, they're not going to allow them to experience failure, they're going to celebrate their successes”.

Care is not only applied to facilitate learning. The holistic approach to students typical of our alternative schools meant care was extended to students’ life circumstances. This involved alleviating poverty and enhancing safety within the schools, as well as supporting students with issues outside the school:

The reality is a lot of the young people here will still have a difficult life and will still face disadvantage for much of their life. But at least at an absolute minimum, if nothing else, when they are at school, they are safe, they are clothed, they're fed. [Catherine, Boronia Flexi School]

Meetings with Care and Protection, going into court, going into hospital with them at times. [Sami, Banksia College]

This kind of commitment from staff enhances distributive justice (Fraser, 1996) in that 
such efforts seek to compensate for the absence of resources and supports in these young people’s lives. In addition, it highlights that "Education is also political work and emotions are manifestations of both transformation and resistance as they inform our cognitive and moral perceptions” (Blackmore, 2004, p. 441). This care is not just about practical matters, but also about students’ emotions:

I think that everyone takes a keen interest in a young person's sort of emotional state and what they're dealing with at home and takes that into consideration and then wants to support them. [Elisabeth, Boronia Flexi School]

Recognition of the emotional elements shaping the lives of young people necessitates a more caring approach to what is normally construed as 'misbehaviour' in other settings. Our case study schools did not ignore such incidents; rather they found patient and creative ways to respond so as to ensure their students were provided with a second (third/fourth/fifth ...) chance.

\section{Second chances}

Speaking back to high stakes testing regimes, a primary school teacher quoted by Kostogriz (2012, p. 405) notes “It's supposed to be about the child, and the child is not numbers. They're feelings, they're emotions”. In our alternative schools, such “appreciation of emotional and sociocultural experiences of children” (Kostogriz, 2012, p. 405) also leads to responding to 'misbehaviour with many 'second chances' rather than with detentions, escalating to suspensions and even expulsion. Adrian (Boronia Flexi School) answered his own question: "How far will you walk with a young person before you say ‘no, we have exhausted all lines of enquiry’? I think we will walk a hell of a lot further than most places will”. His colleague Claudia at the same school argued that when students "in their words, stuff up" they often do not get the chance to 
apologise or make up for their action. In contrast, at Boronia Flexi School staff tried to model a more restorative approach, not only for young people but also for when staff themselves did something wrong:

We acknowledge that might not have been the best choice, or that's a poor choice, but we're not giving up on you. It might take a lot of work for you to repair what you did, or for us to repair what we did, whatever it was, but we're going to.

[Claudia, Boronia Flexi School]

For Dalton (Elkhorn Community College) it was about staff being adult enough not to “carry grudges from one day to the next” and to be "a human that they can make mistakes with, who isn't going to fly back at them”. Julian (Boronia Flexi School) explained that nevertheless there have been some young people for whom staff decided that "it's not safe for them or for us to have them here". However, even then the affective commitment of staff can mean that they would "assist them in finding some other pathway that's meaningful. We don't wash our hands of young people” (Julian, Boronia Flexi School). Blackmore (2004, p. 446) argues that teachers in conventional schools share a similar "desire to promote a moral good, a responsibility to all children”. In practice, however, the approaches to discipline in conventional schools make it difficult for staff to act on such motivations.

Staff commented that their caring and relational approaches did not go unnoticed by students. Troy (Elkhorn Community College) suggested that students have a "recognition that, actually, these people - whether it's teachers, students, whoever they are, guests - actually are there because they give a rip, they actually care”. Hetty (Banksia College, Project-Based Learning Program) pointed out that 'pretending to care’ would not work with their students, that care has to be authentic: "You know, believing the best. That can't be faked. They have got very good BS detectors”. In 
Noddings' terms, such recognition from the cared-for that the one-caring is, in fact, caring is necessary for caring to be "completed in the other" (1984, p. 4).

\section{Enabling affective labour}

\section{Hard work}

The affective work by staff outlined above is 'hard work'i . As Rita (Elkhorn

Community College) put it: "when you hit the ground, you do hit it running here, and it's about building relationships”. The experiences of these staff were different from Hochschild's (1983) notion of emotional labour: their commitment to care tended to be personal rather than imposed by their employer, and the emotions they displayed towards students were, from our observations, authentic rather than fake. Nevertheless, staff appeared to feel the pressure of their own expectations and of the vicarious trauma they were exposed to through their work. The challenges that many students continue to experience can make emotional support confronting and draining for staff. Dalton (Elkhorn Community College), who had worked in the youth sector for many years before going into teaching, provided a vivid example:

All my years doing social policy work, I worked in child protection, social policy, I had no idea how traumatic their lives are. When you hear some of the stories. I had a girl the other day who is pretty hard work but we got to a point where she can talk to me. She's been wanting to get in touch with her father. It will make me cry talking about it, it will, actually. She got in touch with her dad. She hadn't seen him since she was 6 because her folks split up. She was really excited. Her mum has been out of town, so she took the opportunity. And it's just gone pear-shaped because he's not a nice man. He wrote her 14 pages of the most disgusting, vile, offensive stuff. And she's read it. She read the whole thing. But she's so smart. She goes, "No 15-year-old should have to." "Yeah, you are right, you know". She can step out of it and look at it objectively like that. So, anyway. After she read me that letter, then we went on, "What is she doing here? She doesn't do much". But I 
kind of learnt she's beating herself up because she feels she's not getting anywhere in her life. And then you go, "Okay, we have done the right thing". She's found an adult that she can tell that story to. There's a whole lot of learning. She's not doing curriculum learning, maybe, but she's learning an awful lot about trust. [Dalton, Elkhorn Community College - excerpt edited slightly for readability]

As June (Banksia College, Young Parents’ Program) also pointed out in relation to the employment of staff in the program: "Not everybody can come in day in/day out and go through some of the things we go through with the kids and not let it eat you away”. She went on to make the important point that: "they are not poor things who need fixing. If you walk in with that attitude, you won't last five minutes. Because kids feel that”. Research supports this view that such deficit understandings can marginalise students (e.g. Smyth et al., 2010; Te Riele, 2006). Establishing the balance between 'doing good' without being a ‘do-gooder’ is delicate, and can benefit from enacting Lynch’s (2012) notion of solidarity and understanding the students' circumstances as a consequence of social injustices perpetrated against them, often from birth, within and beyond the school system.

Noddings' ethics of care has been criticised by feminist scholars who are concerned that the 'one-caring' is, in effect, carrying out the traditional female role in life of giving much of herself while receiving little in return. For example, Hoagland (1991, p. 255) perceives the one-caring as a "martyr, servant or slave”. This does raise questions of affective justice and prompts questions, as does Lynch’s work, about who is doing the caring work as a matter of social justice.

\section{Intrinsic reward}

Staff in these schools acknowledged that their affective work was emotionally and personally demanding. So why did they keep doing it? The interviews suggest that staff did not see themselves as victims of an ethics of care or of performativity but, 
rather, valued the affective dimension of their work. This is illustrated by William's comment:

This is the first place that when they say 'we work for the best interest of the young people' [...], this is the first place that actually does that which is amazing and makes me feel really emotional. [William, Boronia Flexi School]

Going even further, it may be that some staff (implicitly) agreed with Kostogriz’s (2012) contention that affective labour offers the opportunity for resistance to neoliberal imperatives and allows teachers to focus on the aspects of the work they themselves value. Staff in our research sites seemed to weigh up what to spend effort on in ways similar to a principal in a working class secondary school in the research by Blackmore (2004, p. 446) who stated: “some people don't have a fair go and if I'm going to put my energy somewhere I'd rather put it there than to enhance the privileges of the privileged”. Such intrinsic motivation is dependent on the interests and convictions of staff. Not everyone would find this work inherently rewarding. Noddings (1984, p. 219) points to the role of "love and natural inclination" as opposed to moral obligation. When staff possess this natural inclination, their affective labour is less 'hard work' than if they are acting mainly out of a sense of duty. As Troy (Elkhorn Community College) explained:

You don't do a job like this because it's a job. You have to have a strong sense of vocation and drawing into it, because you wouldn't survive if it was a job.

For staff who do have this sense of vocation, the affective dimensions of their work are rewarding. Blackmore (2004, p. 445) points to "the sense of the pleasures gained from nurturing relationships” in the emotional work of school leaders. Such positive emotions were also expressed by staff in our research: 
I just love coming here. As much as it is challenging and exhausting and tiring, I actually feel like I'm making a difference. [...] Some days you think this is ridiculous, I'm not getting anywhere, but then you get a little gentle reminder but you made so and so feel good today or smile or do this, you know, a couple of minutes out of one day, that's what you've got to look at. [Charlotte, Boronia Flexi School]

\section{Care from students}

Staff felt that they did not just care for students but students also cared for them. This care would appear to provide support for staff to continue with the affective dimension of their work. Julian (Boronia Flexi School) said, “It’s really hard to build those kinds of relationships with these young people but once they're there, they're so loyal to us”. Patrick (Elkhorn Community College) gave the example of a female student who "has a knowledge about compassion and caring. She came up to me some months ago and wanted to instigate Teachers' Day and give the teachers a present”. Apart from being rewarding for staff, such experiences also represent the kind of reciprocity that Lynch (2012) argues is essential for affective justice. Rather than the risk of a "smothering paternalism” (Engster, 2004, p. 116) of students by staff, students are enabled to be the 'one-caring' as well as being 'cared-for'. This was facilitated when the alternative schools offered opportunities for students to lead community meetings or present their learning to others:

Their empathy for us as workers/teachers expands because they see how difficult it is to run a group or how difficult it is to facilitate something; and then they in turn, when they are being participants, are more respectful and more caring. Because that's another thing that's happening lately, I am noticing young people are being more caring of me and of workers. [Rita, Elkhorn Community College]

\section{Collegiality and leadership}

It is difficult for a teacher (or youth worker) to do 'affective labour' on their own. In 
these schools the commitment to care was usually common across most (or even all)

staff. For William (Boronia Flexi School) it was about staff sharing "a real commitment to practising what we preach”. Katrina (Elkhorn Community College) said of other teachers at the site, “These are my people. ... we understand each other”. These comments illustrate a sense of 'being on the same page' that provided collegiality and emotional support for staff. This was evident in practical actions:

Through the strength of our teams that if a young person is having a really tough day and the only adult they're connected to is a teacher who is running a class, someone else will jump in and run that class because that young person needs that relationship at that time. [Claudia, Boronia Flexi School]

Blackmore (2004, p. 444) suggests that: "Workplace cultures shape and are in turn are shaped by individual and collective emotional responses”. In addition to students and colleagues, leaders in alternative schools play a key role in developing the workplace culture. Julian, a staff member at Boronia Flexi School, described the school’s principal as follows:

Her vision for the school and her heart for every individual that's at the school as well and how those two merge together in the every day. I think that's an absolutely special thing that our school and I would contribute a lot of the success that we actually have to her.

Higher up the governance ladder, overarching Boards or Councils can also enable the affective work of staff, as Claudia (Boronia Flexi School) pointed out: “We're a registered school but through the [organisation] we are given the realistic flexibility that we need to take time to develop relationships with young people”. This latter level of support in particular contrasts with conventional schools, where "the importance of emotions and feelings in teaching and learning are highly valued by teachers but seen as obliterated by bureaucracy” (Kostogriz, 2012, p. 405). 


\section{Conclusions}

In foregrounding 'care' in this paper we are not suggesting that attention to care is sufficient for providing a socially just education, or that all these students require is a 'nurturing' environment. This would encourage schools to become drop-in centres. Schools, by definition, have an educative concern. We have stressed elsewhere the importance of students in alternative forms of education experiencing high quality curriculum and pedagogical practices and have been critical of alternative forms of education that do not provide such experiences to their students (McGregor \& Mills, 2014). However, it is apparent from our interviews in these sites that an absence of care and detailed understandings of the affective dimensions of teachers' work in schools works against the interests of highly marginalised students - and indeed their teachers. For many of the teachers in our study this was why they had left the mainstream schooling sector.

The staff participants in our study all expressed a strong commitment to the social and emotional well-being of their students. Affective justice, conceptualised as respectful and caring relationships, was of primary concern to them. These findings raise broader issues related to the teaching profession and affective justice. The schools in which we have been undertaking our research cater to some of the most marginalised young people in Australia. In many cases these young people have been 'evicted' from or 'pushed out' of the conventional schooling system. The research by Blackmore (2004) and Kostogriz (2012) points to staff in conventional schools wanting the opportunity to care, and mourning the ways in which neoliberal policies undermine these opportunities. Yet, students in our research sites had felt a lack of care in their previous, conventional, schools. Staff also made implicit or explicit comparisons, indicating they considered conventional schools less supportive of students. Addressing this needs to 
start in pre-service teacher education. Pre-service teachers, especially for secondary education, may initially be attracted to the profession based on their interest in a particular discipline. They tend to soon realise, however, that they will not simply be teachers of history or of mathematics - rather, they will be teachers of young people. Boler (1999, p. xvii) argues that: "Emotions function in part as moral and ethical evaluations: they give us the information about what we care about and why”. Attending to these emotions in pre-service teaching is not easy - universities are also affected by performativity and (often overly detailed) lists of mandated content - but, our findings suggest, is vital for preparing pre-service teachers for the fundamental affective dimension of teachers' work.

Our findings also point to enablers of affective labour. Key is the sense of satisfaction staff gained from foregrounding care and relations. Many of the workers that we spoke to expressed the joys of working in the alternative sector compared to the mainstream. Nevertheless, affective labour was hard work and there were also costs associated with such work. The engrossment and motivational displacement exhibited by staff, and considered a requirement for ethics of care by Noddings (1984), can generate considerable emotional strain. For the staff in our alternative schools, the support of their students, colleagues and leadership was essential for sustaining their affective work. This interpersonal scaffold applies beyond alternative schools. Blackmore (2004) foregrounds the imperative for school leaders to build "a positive emotional economy based on collaborative models of professionalism” (p. 456) and argues (p. 444):

Emotions are part of the social glue that hold organizations together as they tap into why individuals make particular choices, how they work with others and relate to the organization and how they evaluate their situation. 
For colleagues and leaders in conventional schools, this offers the potential that emotions can be harnessed for enabling each other to choose to prioritise their students' benefit over “compliance with policy and standards laid down elsewhere” (Blackmore, 2004, p. 454). A specific emotion considered productive by both Blackmore (2004) and Kostogriz (2012) is anger. An anger, not directed at students, but at a system that hinders attempts to care. This leads to our final concluding comment.

In the paper we have focussed on care, and have only alluded to Lynch's notion of solidarity in passing, i.e.: "the more political or public face of affective relations" (Lynch, 2012, p. 52). However, it is important to acknowledge that whilst the vast majority of workers in all these sites exerted significant emotional labour in their work with individual students, most also appeared to have a broader political commitment to marginalised young people. It was solidarity relations which had drawn them to work in these schools in the first place. Such solidarity, and anger at the impact of performativity on their capacity for affective work, can also prove to be a strong motivator for staff in conventional schools. As Kostogriz (2012, p. 406) explains:

Feelings of anger and frustration are common as a starting point of their [teachers] critical reflection on educational and political leadership. [... This] triggers not only teachers' demoralization but also a covert resistance to, and subversion of, standards-based accountability measures.

Ultimately all schools, and the staff and students within them, are limited in what they can do by structural inequalities and counterproductive policies. But that does not mean teachers should stop trying to do better. As our staff in alternative schools demonstrate, it is possible to re-capture the affective dimensions of teaching. And as their students told us (Mills, McGregor, Baroutsis, et al., 2015) the outcome is to enable learning and enhance wellbeing, bringing benefits both to these young people and to society. These examples generate hope for teachers in conventional schools and - if they can act on the 
inspiration provided here - may reduce the need for young people (and staff) to escape from the mainstream to alternative settings.

\section{Acknowledgements}

The research on which this paper is based has been developed from an Australian Research Council funded Discovery Project (DP120100620). Additional data were drawn from an Australian Research Council funded Linkage Project (LP130100344).

\section{References}

Apple, M. (2004). Ideology and curriculum (3rd ed.). New York, NY: RoutledgeFalmer.

Apple, M. (2006). Educating the 'right' way (2nd ed.). New York, NY: RoutledgeFalmer.

Apple, M. (2010). Global crises, social justice and education. New York, NY: Routledge.

Ball, S. (2012). Global education Inc.: New policy networks and the neo-liberal imaginary. London: Routledge.

Bingham, C., \& Sidorkin, A. (Eds.). (2004). No education without relation. New York, NY: Peter Lang.

Blackmore, J. (2004). Leading as emotional management work in high risk times: The counterintuitive impulses of performativity and passion. School Leadership and Management, 24, 439-459. doi:10.1080/13632430410001316534

Boler, M. (1999). Feeling power: Emotions and education. New York, NY: Routledge.

Bridgeland, J., Dilulio, J., \& Morison, K. (2006). The silent epidemic: Perspectives of high school dropouts. Washington, DC: Civic Enterprises.

Engster, D. (2004). Care ethics and national law theory: Towards an institutional political theory of caring. Journal of Politics, 66, 113-135. doi:10.1046/j.14682508.2004.00144.x

Evans, J., Meyer, D., Pinney, A., \& Robinson, B. (2009). Second chances: Re-engaging young people in education and training. Ilford, UK: Barnardo’s. 
Fraser, N. (1996). Social justice in the age of identity politics: Redistribution, recognition, and participation. Paper presented at The Tanner Lectures on Human Values, Stanford University. Retrieved from: http://tannerlectures.utah.edu/_documents/a-to-z/f/Fraser98.pdf

Fraser, N. (2009). Scales of justice: Reimagining political space in a globalizing world. New York, NY: Columbia University Press.

Hardy, I. (2013). Competing pressures in practice: Teachers' pedagogies and work under complex policy conditions. International Journal of Pedagogies and Learning, 8, 206-218. doi:10.5172/ijpl.2013.8.3.206

Hayes, D. (2012). Re-engaging marginalised young people in learning: The contribution of informal learning and community-based collaborations, Journal of Education Policy, 27, 641-653. doi:10.1080/02680939.2012.710018

Hoagland, S. (1991). Some thoughts about caring. In C. Card (Ed.), Feminist ethics (pp.246-263). Lawrence: University Press of Kansas.

Hochschild, A. (1983). The managed heart. Berkeley: University of California Press. Hopman, J., \& Drake, P. (2015). The emotional workload of teachers is too often ignored. The Conversation. Retrieved from: http://theconversation.com/theemotional-workload-of-teachers-is-too-often-ignored-48013

James, N. (1989). Emotional labour: Skill and work in the social regulation of feelings. Sociological Review, 37, 15-42. doi:10.1111/j.1467-954X.1989.tb00019.x

Keddie, A. (2012). Educating for diversity and social justice. New York, NY: Routledge.

Kostogriz, A. (2012). Accountability and the affective labour of teachers: A MarxistVygotskian perspective. Australian Educational Researcher, 39, 397-412. doi:10.1007/s13384-012-0072-X

Lynch, K. (2012). Affective equality as a key issue of justice: A comment on Fraser's 3dimensional framework. Social Justice Series, 12(3), 45-64. Retrieved from: http://hdl.handle.net/10197/4400

Mackie, A., \& Tett, L. (2013). 'Participatory parity', young people and policy in Scotland. Journal of Education Policy, 28, 386-403. doi:10.1080/02680939.2012.761729

McGregor, G. \& Mills, M. (2012). Alternative education sites and marginalised young people: 'I wish there were more schools like this one'. International Journal of Inclusive Education, 16, 843-862. doi:10.1080/13603116.2010.529467 
McGregor, G, \& Mills, M. (2014). Teaching in the 'margins': rekindling a passion for teaching. British Journal of Sociology of Education. 35, 1-18.

doi:10.1080/01425692.2012.740813

Merriam, S. (2009). Qualitative research: A guide to design and implementation. San Francisco, CA: Jossey-Bass.

Miles, M. \& Huberman, A. (1994). Qualitative data analysis: An expanded sourcebook (2nd ed.). Thousand Oaks, CA: Sage.

Mills, D. \& Morton, M. (2013). Ethnography in education. London: SAGE.

Mills, M. \& McGregor, G. (2014). Re-engaging young people in education: Learning from alternative schools. London: Routledge.

Mills, M., McGregor, G., Baroutsis, A., Te Riele, K., \& Hayes, D. (2015). Alternative education and social justice: Considering issues of affective and contributive justice. Critical Studies in Education, 57, 100-115.

doi:10.1080/17508487.2016.1087413

Mills, M., McGregor, G., Hayes, D., \& Te Riele, K. (2015). 'Schools are for us'. The importance of distribution, recognition and representation to creating socially just schools. In S. Riddle, A. Black \& K. Trimmer (Eds.), Researching mainstreams, margins and the spaces in-between (pp. 152-169). London: Routledge.

Noddings, N. (1984). Caring: A feminine approach to ethics and moral education. Berkeley: University of California Press.

Noddings, N. (2003). Is teaching a practice? Journal of Philosophy of Education, 37, 241-251. doi:10.1111/1467-9752.00323

Noddings, N. (2005). Identifying and responding to needs in education. Cambridge Journal of Education, 35 (2) 147-159. doi:10.1080/03057640500146757

Smyth, J., Down, B., \& McInerney, P. (2010). 'Hanging in with Kids' in tough times: Engagement in contexts of educational disadvantage in the relational school. New York, NY: Peter Lang.

Te Riele, K. (2006). Youth 'at risk': Further marginalizing the marginalized? Journal of Education Policy, 21, 129-146. doi:10.1080/02680930500499968

Te Riele, K. (2012). Negotiating risk and hope: A case study of alternative education for marginalized youth in Australia. In W. Pink (Ed.), Schools and marginalized youth: an international perspective (pp. 31-79). Cresskill, NJ: Hampton Press. 
Thomson, P. (2014). What's the alternative? Effective support for young people disengaging from the mainstream. Literature Review. London: The Prince’s Trust. Retrieved from:

https://alternativeducationresearch.files.wordpress.com/2014/10/literaturereview-final-15-10-14.pdf

Ungar, M. (Ed.) (2012). The social ecology of resilience. Rotterdam: Springer.

${ }^{\mathrm{i}}$ A broad conceptualisation of resilience is relevant here, but is beyond the scope of this paper to discuss. If interested, we suggest a good starting point is Ungar (2012). 